\title{
Title: International production and trade in a high-tech industry: a multilevel network analysis.
}

\section{Authors}

Matthew Smith ${ }^{1}$

Centre for Business Network Analysis, University of Greenwich, Business School, Park Row, Greenwich, London SE10 9LS, United Kingdom

M.Smith@greenwich.ac.uk

\section{Sara Gorgoni ${ }^{1}$}

Centre for Business Network Analysis, University of Greenwich Business School, Park Row, Greenwich, London SE10 9LS, United Kingdom

S.Gorgoni@greenwich.ac.uk

\section{Bruce Cronin ${ }^{2}$}

Centre for Business Network Analysis, University of Greenwich Business School, Park Row, Greenwich, London SE10 9LS, United Kingdom

C.B.Cronin@greenwich.ac.uk

Accepted Version: May 2019

\begin{abstract}
We propose a multilevel network approach as an alternative framework to analyse the international organisation of an industrial sector. We present a novel application of a multilevel Exponential Random Graph Model to a multilevel network of firms linked by ownership at the micro level, countries linked by trade at the macro level, and a firm-county affiliation network linking the two in a high-tech industry. The results from the multilevel ERGM reveal a complex interplay between firm-level activity and international trade patterns. The approach can be extended to other industries to improve understanding of the international organisation of production, to map global value chains and to compare industries.
\end{abstract}

\footnotetext{
${ }^{1}$ University of Greenwich
} 


\section{Highlights}

- Applies the multilevel exponential random graph model to a novel dataset of international trade and ownership.

- Examines the international production in a high-tech sector (medical and precision instruments).

- The results from the multilevel ERGM highlight the complex interplay between firmlevel activity and international trade patterns.

- This approach could be extended to or replicated in other industries, to map global value chains or to compare the international organisation of production across different industries.

\section{Keywords}

- Exponential random graph models

- Multilevel networks

- International organisation of production

- International trade

- Corporate ownership network 


\section{Introduction}

Twenty-first century production is fragmented into a number of stages, geographically distributed internationally, which has led to a rise in the level of trade in intermediate goods (Helg and Tajoli, 2005). This international reorganisation of production arises from outsourcing (Jones and Kierzkowski, 2005), as well as from the development of what Hanson et al. (2005) call "vertical production networks", which describes the trade between the parent and affiliate companies located abroad (intra-firm trade).

The international organisation of production poses a challenge for the use of existing datasets to explain features of the modern global economy. In particular, there are insufficient data to document patterns of intra-firm trade central to international production. The need to include firm-level activity in combination with country-level data to explain production, has been recognised by several scholars (Bernard and Moxnes, 2018; De Backer et al. 2018; Nielsen, 2018; Cadestin et al., 2018), who have advocated the development of more detailed datasets to explain the complex patterns of international production.

In recent years, network analysis of international trade and corporate ownership has been used to understand features of the modern global economy. Whilst these studies overcome many limitations of a bilateral approach, specifically taking in account the complex interdependencies between actors, they consider international trade and firm-level activity in isolation, abstracting from the reality that country-level patterns of trade are a result of firmlevel activity.

This paper aims at filling this gap by combining firm- and country-level data to overcome the abstract separation between the micro and the macro levels and to better explain the international organisation of a sector, to inform on aspects of global production. We examine the case of medical and precision instruments, a high-tech industrial sector. We build a multilevel relational dataset with firm ownership data from Orbis and country-level international trade data from UN Comtrade (United Nations Commodity Trade Database) and use a multilevel network model to investigate the micro determinants of ties observed at the macro level. We demonstrate how to combine these different secondary data sources and the aspects of production that a multilevel analysis can illuminate.

The paper is structured as follows: section two reviews the extant literature, applying network analysis to the international organisation of production. This section outlines the rationale for 
a multilevel network perspective, together with the contributions of a multilevel analysis. Section three describes the industrial sector under examination - the manufacture of medical and precision instruments. It also presents the multilevel dataset, along with a brief descriptive analysis of the multilevel network. Section four discusses the Exponential Random Graph Model (ERGM) that we employ to analyse the multilevel network. Section five presents the results, and the final section provides concluding comments and a discussion of possible avenues for future research.

\section{Literature review}

\subsection{Network analysis and the international organisation of production}

A variety of methodological approaches have been used to analyse the international organisation of production in a variety of industries and to account for the increased trade in parts and components.

A qualitative approach which has contributed significantly in understanding the international organisation of production and the sectoral level has been Global Value Chain (GVC) analysis (Gereffi et al., 2005). GVC analysis maps the production of a good from its conception to end use and beyond over a wide geographic space, primarily addressing research questions such as where value is added along the chain and where is it extracted. Whilst a very useful conceptual tool in examining production patterns, the methodological approach is typically qualitative case study; this has deepened our understanding of how production is organised in specific sectors and value chains but has limited generalisability.

Parallel to the GVC approach, a strand of literature in international economics has examined the international organisation of production in a quantitative manner, generally drawing on gravity and general equilibrium models (see Antràs and Yeaple, 2014 for a review). Most of the literature in international economics uses the gravity model (or some variant), the standard-bearer in the analysis of international trade (Ward et al., 2013). This is the argument that bilateral trade flows among countries are inversely proportional to the geographic distance between them. The gravity model is a very successful empirical model in predicting bilateral trade flows and recent extensions of the modelling approach (as seen in Charbonneau, 2017; Graham, 2015) can even account for third order dependencies amongst countries in cross sectional data. But recently, more detailed studies have recognised the 
international organisation of production and not just transport distance as critical determinants of international trade flows (Yi, 2003). Recently, there have been several empirical implementations of the gravity model utilising input-output data, mapping value added between countries at an industry level, thereby overcoming some of the limitations of trade or detailed transaction data (Johnson 2014; Johnson and Noguera, 2017). However, input-output data are also subject to several limitations, especially in terms of coverage. Compared to international trade data, input-output data cover significantly fewer countries, and only provides information on a narrow selection of sectors, defined at a broad aggregated level.

This more recent international economics literature draws from property right theory (as described by Grossman and Hart, 1986) to argue that incomplete contracts govern the tradeoff between outsourcing and offshoring in production and that the enforcement of incomplete contracts has a particularly acute effect on transactions and trade of intermediate inputs, especially those which are unique or highly specialised to the buyer-supplier relationship (Antràs, 2003; 2005). These transactions between unrelated parties can require investment in the relationship, as buyers would suffer from time lags in production if they have to source specialised inputs elsewhere during contract disputes. Additionally, the supplier would struggle to sell these goods to alternative buyers (Antràs and Chor, 2013).

This approach has been extended to consider how economic environmental factors (trade costs, factor prices, communication and technology) splits production into geographically fragmented stages (Antràs and Rossi-Hansberg, 2009). Within this literature, Baldwin and Venables (2013) counterpoise two ideal type value chain configurations - 'snakes' and 'spiders'; where snakes are production processes where a commodity is constructed in a sequential process with each operation adding value in a predetermined order, while spiders bring parts together for assembly. These differing configurations have differing implications for the bundling and unbundling of production and responsiveness to cost differences at different locations and the corresponding impact on international trade volumes.

A further contribution to the understanding of the international organisation of production comes from the multinational production literature, which explains patterns and trends of intra-firm trade, that is, trade amongst firms affiliated by ownership. Intra-firm trade has been found to adhere to the gravity model (Yeaple, 2009; Keller and Yeaple, 2013; Irarrazabal et 
al., 2013) and intra-firm trade is skewed, where only a handful of very productive firms participate in intra-firm trade (Haller, 2012; Ramondo et al., 2016).

This stream of literature clearly argues the need to consider the firm as the unit of analysis to uncover patterns of trade, and the interaction with multinational production; a large amount of firm heterogeneity lies behind aggregated international trade data at the country-level (Ramondo, 2014). This modelling approach provides valuable contributions in explaining production patterns, in particular the increasingly important role of multinationals, yet is often reliant on detailed national data, which is only available for a handful of nations, such as the data provided on US multinational firm activity from the US Census Bureau database (Helpman, 2014). Although this data contains information on firm-level trading patterns (such as levels of intra-firm trade) it is aggregated to the country-level, mapping these transactions between the focal country and partners.

A related strand of literature in international economics attempts to explain the trading patterns of firms, starting with the important contribution of Melitz (2003). Melitz (2003), along with subsequent extensions (including Helpman et al., 2004; Bernard et al., 2007; Chaney, 2008) develops a general equilibrium model that accounts for the heterogeneity of firms in order to explain patterns of international trade. In particular, there is an emphasis on how this heterogeneity explains why some firms export within industries and others do not; high-productivity firms tend to expand and enter export markets, whilst low-productivity firms tend to exit these. This approach is particularly useful in addressing research problems on how firms choose to serve foreign markets (FDI or exporting) and how they enter and exit these markets. However, similar to the multinational production approach, these models are reliant on detailed plant level information (aggregated to the country-level), which is widely unavailable, or only available for a handful of nations.

In the few countries where detailed firm-level transaction data is provided by statistical agencies, such as in the US, Japan and Germany, these international economics models are mainly used to address three central research questions. Firstly, why do some firms operate in more than one country? Secondly, what determines the country location of production facilities? Finally, why do firms own foreign facilities rather than trading with contract suppliers? In this way, these modelling approaches have contributed in addressing important research questions to understand key features of the global economy. However, these questions cannot be applied to all firms regardless of country of origin, only to those where 
detailed data is available on firm-level activities at the country-level and the share of the country's trade that is intra-firm for an industry. Additionally, there is a focus on the single bilateral relationship between a parent firm and its subsidiary or external contract manufacturer in the foreign market. Thus, the data neglect firms that are part of a corporate network (such as a business or multinational group), that also shape investment or trading choices.

Network analysis presents a technique to complement these approaches in international economics. Whilst the gravity model has empirical success in explaining inter-country trade flows (and in some cases accounting for dependencies amongst countries) on the basis of country characteristics, statistical network models allow a different set of research problems to be addressed. Statistical network models typically directly model the topology of the network of inter-country trade, allowing for relational hypothesis to be tested, such as the distribution of trade ties amongst countries, and whether we observe hierarchical trading patterns. The focus on country characteristics of the gravity model and related methodologies tend to leave these phenomena un-modelled (Pan, 2018). Therefore, network approaches provide a valuable contribution to complement the existing approaches in international economics.

A branch of international economic literature has applied network analysis to international trade data to understand patterns in the global economy (Garlaschelli and Loffredo, 2005; Fagiolo et al., 2009; De Benedictis and Tajoli, 2011; De Benedictis et al., 2014), primarily addressing questions related to the level of integration of countries in the global economy (Kali and Reyes, 2007), regionalisation trade patterns (Iapadre and Tajoli, 2014; Zhu et al., 2014) and to test hypothesis from world systems theory (Smith and White, 1992). However, there are only a limited number of studies where network analysis has been used to specifically investigate the international organisation of production (Amighini and Gorgoni, 2014; Blázquez and González-Díaz, 2016; Gorgoni et al., 2018).

\subsection{The contribution of a multilevel network approach}

A crucial issue in investigating the organisation of production is the fact that the majority of studies lack recognition - in terms of empirical analysis - of the multilevel nature of the phenomenon. 
Apart from some notable exceptions such as Metulini et al. (2017), most studies examine trade in isolation from Foreign Direct Investment (FDI) decisions, yet this is clearly not a realistic assumption in a world where production is a globally fragmented process, with many multinational and corporate groups utilising FDI and locational assets in their manufacturing activities to retain competitive advantages (Gray, 1996). But Gammeltoft et al. (2010) note that studies that do make use of FDI stock and flow statistics only illustrate overall country patterns, neglecting the fact that FDI flows comprise an aggregation of firm-level activities. Further, since firms are widely linked by ownership as business groups, international trade and investment flows are dependent on corporate networks (Park and Park, 2015; Wacker, 2016). Altomonte and Rungi (2013) argue that such business groups play a key role in the unbundling of the production process; UNCTAD (United Nations Conference on Trade and Development) (2013) estimated that these groups accounted for $80 \%$ of total trade in 2010.

Metulini et al. (2017) make use of a network approach to examine the effects of FDI on international trade, demonstrating the complicated dependencies between patterns of international trade and investment. They create a country network of FDI from firm-level cross-country ownership relationships, which they refer to as the corporate control network $(\mathrm{CCN})$. They apply a gravity model approach and find that the $\mathrm{CCN}$ has a positive and significant effect explaining international trade, therefore, highlighting the need to incorporate firm-level information for a better understanding of patterns of international trade and production.

The need to combine firm-level and country-level data has been acknowledged by several other scholars (amongst them Miroudot et al., 2009). Current datasets, however, lack the necessary detail. Feenstra et al. (2010) recognise this in their examination of the state of available data for the study of international trade and FDI. They suggest that in order to better understand the complicated nature of production as it is today, there is a need for datasets to capture the increasing importance of MNEs and intra-firm trade, a view echoed by multilateral institutions. For instance, a WTO (World Trade Organisation) - OECD (Organisation for Economic Co-operation and Development) collaborative initiative has resulted in a new dataset, Trade in Value Added, which maps valued added patterns utilising aggregate industry-level Input-Output tables (OECD, 2013). 


\section{Data \& analysis}

\subsection{The context -industry for medical \& precision instruments}

The industrial sector analysed in this study is broadly categorised as the medical and precision instruments, including items such as ultrasound machines and MRI systems. This can be classified in Lall et al.'s (2006) schema as a high-tech sector.

The industry is highly concentrated (Bamber and Gereffi, 2013), with a handful of firms accounting for around $40 \%$ of the overall market share and lead firms primarily headquartered in the US (Porter et al., 2011). The industry is greatly integrated vertically, with many production activities taking place in-house, yet not necessarily in the same geographic location. The focus on retaining activities in-house is a result of the regulatory approval for product specifications which are difficult to extend to contract manufacturers. The regulatory diversity across nations has led to many firms establishing a presence in multiple end-markets and often acquisition of firms primarily for their regulatory advantages (Sturgeon et al., 2016).

\subsection{Data}

The selection of appropriate data is a key component in investigating the phenomenon of the international organisation of an industry and aspects of global production. Additionally, in order to pursue a multilevel analysis, matching data at both micro- and macro-levels is essential. This study takes the product as the framing level, considering product trade at the macro level and the product production at the micro. The perspective of the product (or function or task, as it has also been referred to) has been argued as more relevant than the aggregated sector level when critically discussing issues in the area of the international organisation of production (Grossman and Rossi-Hansberg, 2008; Baldwin and RobertNicoud, 2014), as a finished product is now generated through trade in intermediate goods (Timmer et al., 2013).

There are two approaches that could potentially be used to map the international organisation of production at the country-level; firstly, Input-Output (I-O) tables could be used to measure trade in intermediate inputs; the alternative approach is to examine the trade patterns of components at a high level of disaggregation (Srholec, 2006). Because I-O tables are only available at a high level of aggregation, this study takes the latter approach, making use of highly disaggregated trade data (at the 5 digit SITC Rev 3 level), extracted from the UN 
Comtrade database, for the year 2012. The industry under examination here is the manufacture of optical and medical instruments; this corresponds to 77421 , the manufacture of "x-ray, radiography, or radiotherapy apparatus."

The trade data from UN Comtrade are used to build the macro level, International Trade Network (ITN), where a tie is directed from the exporter to the importer. A threshold was applied to the data to ensure that only the most relevant ties were retained yet preserving the network structure (an approach frequency observed in network studies of international trade, including Shore, 2016). This procedure also helped in omitting countries which do not significantly contribute to trade yet increase levels of reciprocity. The threshold for the retained trade ties was $0.01 \%$ of the value of total trade of industry 77421 . This threshold was determined by examining the proportion of world trade that was retained by applying the threshold, to ensure the network represented the majority of global trade. The $0.01 \%$ cut retained $97 \%$ of world trade.

Various strategies have previously been pursued to select the most important ties to retain in the construction of an ITN. Zhou et al. (2016) present a unique approach; constructing the network on the basis of retaining each nation's top export flow(s). They argue that the value of this approach is that it guarantees the inclusion of all nations in the network and allows to control for the density of the network. In this case, we are less concerned with retaining all nations, rather preserving those that play a significant role in the sector. Therefore, the application of a threshold allows for the consideration of the most important nations and valuable trade ties in the sector.

Bureau van Dijk's Orbis database was used to build the micro level ownership network, along with the firm-country affiliation network. This database has been used in the construction of ownership networks in a variety of studies (Glattfelder and Battiston, 2009; Vitali et al., 2011; Vitali and Battiston, 2014). The main issue in the construction of the micro-level network was the selection of firms that manufacture the product classification used in the construction of the macro-level network. The procedure used to select these initial firms was to identify firms associated with the relevant commodity code used to construct the trade network.

As the two databases do not use the same coding systems, it is necessary to translate between the coding classifications. Eurostat maintains a set of correspondence tables among different 
statistical classification systems (Eurostat, 2017). ${ }^{2}$ Thus, linking the correspondence tables provides a method of systematically mapping NACE classifications to SITC classifications (ISDATA, 2017). By this means it is possible to map NACE code 266 "Manufacture of irradiation, electromedical and electrotherapeutic equipment" to SITC code 77421 "Manufacture of x-ray, radiography, or radiotherapy apparatus."

In addition to the use of the correspondence table, an additional inspection of the products produced by each firm was undertaken (as Orbis provides an overview of production activities of manufacturing firms), to ensure that these firms properly matched the trade level at the macro level. From this list the ownership network was constructed, linking parents and subsidiaries that are involved in the manufacture of medical and precision instruments.

The micro-level network has firms as actors, ties as an ownership relationship, directed from the parent firm to the subsidiary. Following previous studies, such as Del Prete and Rungi (2017), the ownership ties were included when the parent directly owned the majority $(50.01 \%)$ of the subsidiary. Direct majority ownership was selected for several additional reasons. Firstly it allows us to capture corporate control within business groups, where parents have sufficient managerial influence over subsidiaries (Rungi et al., 2017). Secondly, this approach provides a stricter definition of "related parties" amongst firms, therefore, the dataset is better suited to an analysis which attempts to comment on patterns of intra-firm trade (trade between related parties). We utilise this approach to create a binary, directed network of firms linked by ownership, where the relations between firms represents the sender's majority ownership of the receiver. This positional strategy in defining the ownership network boundary ensures that only firms directly occupying a place in the manufacture of medical and precision instruments were included, yet this strategy results in a number of disconnected actors, with a set of small, separate connected components lacking ties between them (Knoke and Yang, 2008).

The firm-country affiliation network was then constructed using the Orbis database. The information that was utilised in the construction of this level was the national location information of each of the firm's branches, where they have production, distribution and sales

\footnotetext{
${ }^{2}$ There are no direct correspondence tables between NACE and SITC classification systems, but an indirect link is available via correspondence tables between NACE and the International Standardised Industry Classification (ISIC), ISIC and the United Nations Harmonised System (HS) and between HS and SITC.
} 
sites. The full multilevel network therefore contains three types of ties: trade flows between countries, ownership ties between firms and the ties between firms and countries, based on the location of firms. Visualisations of the full multilevel networks can be found in figure 1, where red nodes represent firms, and blue nodes countries. In the remainder of the paper the firm-level ownership network is referred to as the micro level, the international trade network as the macro level and the firm-country affiliation network as the meso level, in line with the terminology utilised in multilevel network analysis.

Figure 1 - Full multilevel network

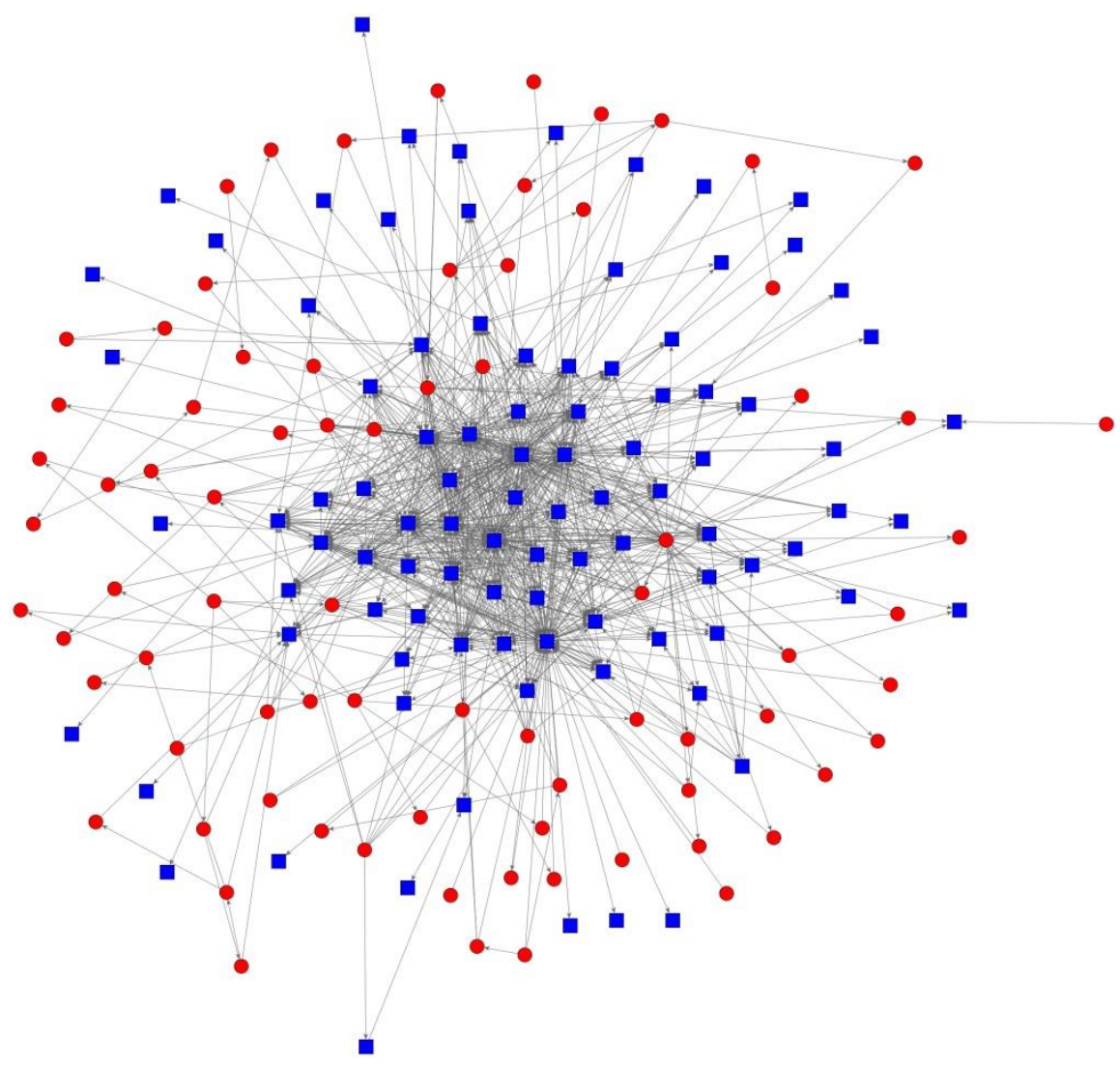

Note: Blue squares are countries and red circles are firms

\subsection{Descriptive analysis of the networks}

This section provides an initial descriptive analysis of the networks separately, in order to identify the most prominent firms and nations in the network. ${ }^{3}$

Table 1 provides a summary of the network level statistics for both the international trade and

${ }^{3}$ The descriptive network statistics are calculated using a combination of UCINET (Borgatti et al., 2002) and the R package Statnet (Handcock et al., 2016). The network visualisations were created using Visone (Baur et al., 2001). 
ownership networks, highlighting the two very different network structures at the macro and micro levels. At the macro level, we observe patterns of clustering, complex degree distributions (as indicated by the centralisation results) and reciprocity. At the micro level, the descriptive network statistics, more specifically, the lack of clustering and reciprocity point towards a network characterised by a more hierarchical star structure.

Table 1 - Descriptive Statistics for Trade \& Ownership Networks

\begin{tabular}{|l|c|c|}
\hline & Trade Network & Ownership Network \\
\hline Size (No. of Nodes) & 95 & 68 \\
\hline Density & 0.0648 & 0.0105 \\
\hline Reciprocity & 0.3247 & 0 \\
\hline Transitivity & 0.4910 & 0 \\
\hline Average Degree & 12.1895 & 1.4118 \\
\hline Out-Degree Centralization & 0.6871 & 0.2165 \\
\hline In-Degree Centralization & 0.1603 & 0.0046 \\
\hline Clustering Coefficient & 0.7319 & 0 \\
\hline
\end{tabular}

The macro network visualisation, presented in figure 2 together with the high clustering coefficient in table 1 and the core-periphery density matrix in table 2, suggest that the trade network is characterised by a core-periphery structure. Table 2 presents the members of the core along with the final fitness for the network. The core-core high density score of 0.814 indicates that there is a small, tightly connected group of countries, which accounts for most of the trade within this sector, surrounded by countries loosely connected to the core, and not connected to other countries outside the core. The low periphery-periphery density, points towards members of the periphery excluded from a high number of trading relationships, and dependent on trade with the core. These results of the core-periphery analysis suggest that trade (and therefore production) in the medical and precision instruments is characterised by a hierarchical division of labour, with a set of key countries playing a significant role in the production process, and others playing a dependent or confined role. 
Figure 2 - Macro level international trade network

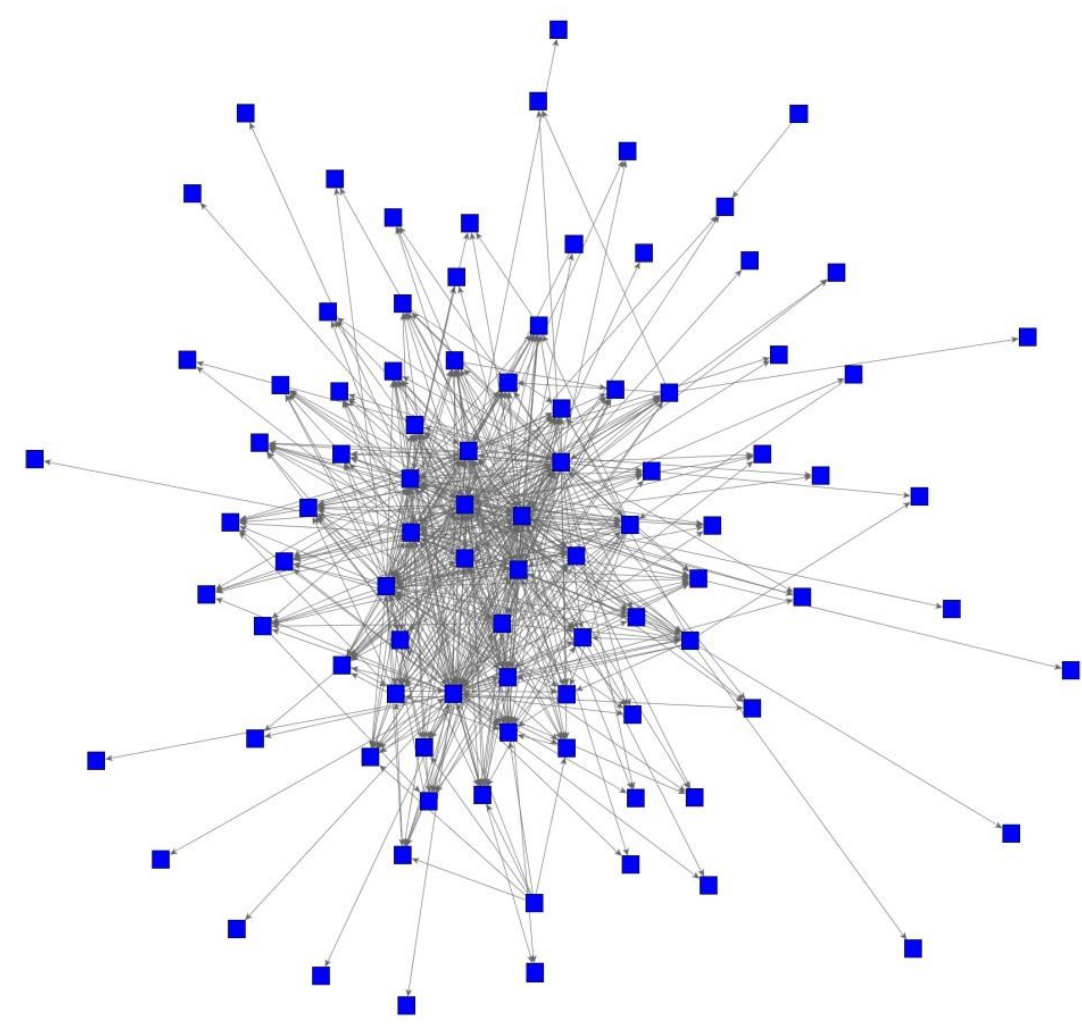

Table 2 - Core-periphery analysis of the international trade network

\begin{tabular}{|c|l|l|ccc|c|c|}
\hline Core & $\begin{array}{l}\text { USA, Germany, China, } \\
\text { Japan, Netherlands, UK, }\end{array}$ & Density & & C & P & Final Fitness & 0.789 \\
$\begin{array}{l}\text { Finland, France, Italy } \\
\text { Republic of Korea, Spain, } \\
\text { Switzerland, Malaysia }\end{array}$ & Matrix & C & 0.814 & 0.343 & & \\
\hline
\end{tabular}

The core is prominently dominated by European nations, along with the USA, the key areas in terms of demand in the sector. The Republic of Korea's prominent position in the network may be a result of the Korean firm Samsung Electronics and its investment in the medical devices sector in 2011, along with the country's proximity to the related electronics value chain.

The dominance of the USA and Europe is also demonstrated in Figure 3. This presents a geographical map, where countries included in the analysis (present in the full multilevel network) are highlighted in red and are grey otherwise. Figure 3 clearly shows that European nations feature predominantly in this sector, whereas nations from sub-Saharan Africa are far 
less active in this sector.

Figure 1 Geographic Map of countries included in multilevel analysis

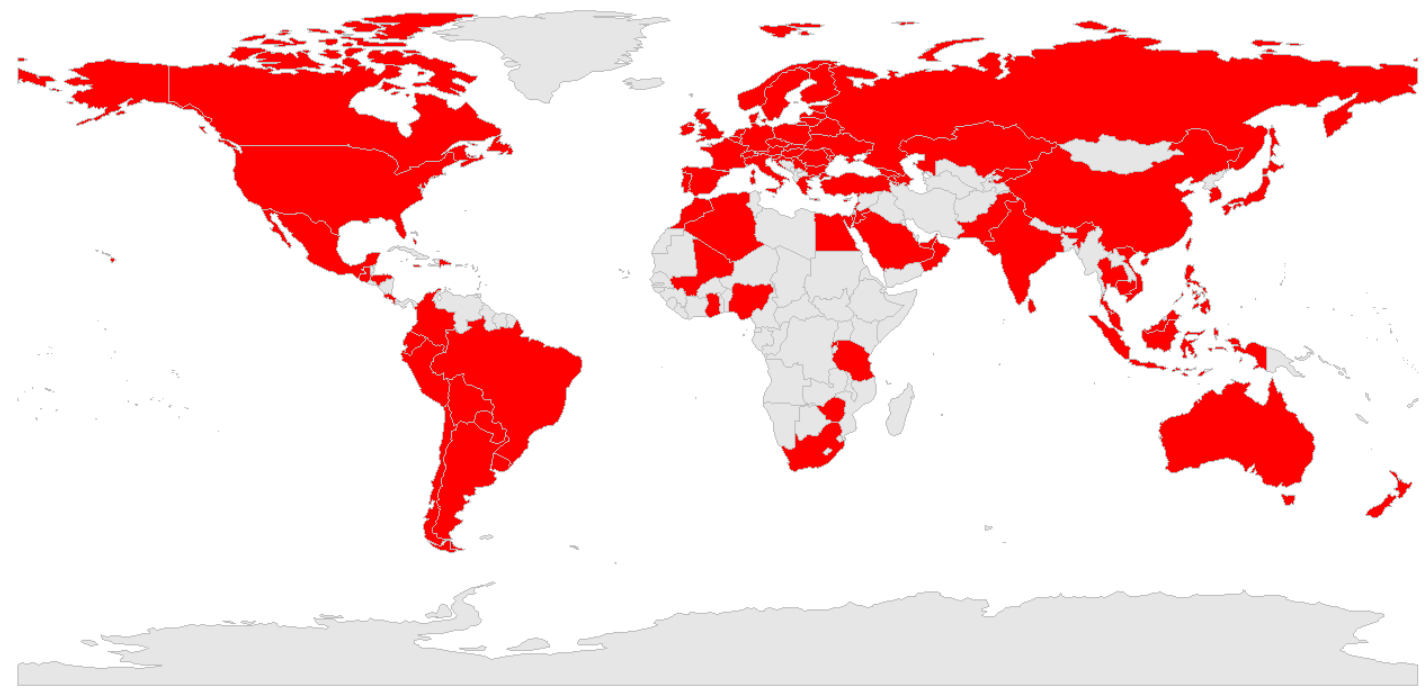

Note: Countries highlighted in red are included in the multilevel dataset and analysis

Table 3 - Descriptive statistics for country attributes

\begin{tabular}{|c|c|c|c|c|c|c|c|c|c|c|}
\hline Region & $\begin{array}{l}\text { East Asia } \\
\& \text { Pacific }\end{array}$ & Europe & $\begin{array}{l}\text { Central } \\
\text { Asia }\end{array}$ & $\begin{array}{l}\text { Lati } \\
\text { Am } \\
\text { Car }\end{array}$ & $\begin{array}{l}\text { ca \& } \\
\text { ean }\end{array}$ & $\begin{array}{l}\text { Middle } \\
\text { East \& } \\
\text { North } \\
\text { Africa }\end{array}$ & $\begin{array}{l}\text { North } \\
\text { America }\end{array}$ & Oceania & $\begin{array}{l}\text { South } \\
\text { Asia }\end{array}$ & $\begin{array}{l}\text { Sub- } \\
\text { Saharan } \\
\text { Africa }\end{array}$ \\
\hline $\begin{array}{l}\begin{array}{l}\text { No. of } \\
\text { Countries }\end{array} \\
\end{array}$ & 12 & 32 & 10 & 17 & & 9 & 2 & 2 & 3 & 8 \\
\hline \multicolumn{3}{|c|}{$\begin{array}{c}\text { Continuous Attributes } \\
\text { (normalised) }\end{array}$} & \multicolumn{2}{|c|}{$\begin{array}{l}\text { Number of } \\
\text { countries }\end{array}$} & \multicolumn{2}{|c|}{ Mean } & SD & & \multicolumn{2}{|c|}{ Median } \\
\hline \multicolumn{3}{|c|}{ GDP } & \multicolumn{2}{|l|}{95} & \multicolumn{2}{|c|}{0.33} & 0.94 & & \multicolumn{2}{|l|}{0.07} \\
\hline \multicolumn{3}{|c|}{ GDP per capita } & \multicolumn{2}{|l|}{95} & \multicolumn{2}{|c|}{0.67} & 0.74 & & \multicolumn{2}{|l|}{0.38} \\
\hline
\end{tabular}

Table 3 provides additional information on attributes of countries in the international trade network. The regional partitions (along with figure 3 ) indicate that trade in this sector is dominated by countries from Europe, where demand for products in the sector is also high. The distribution of GDP and GDP per capita suggests that market size (GDP) is more dispersed than market affluence (GDP per capita).

The ownership network is presented in figure 4. We observe that this network is characterised by several star structures, centred on a focal firm. These firms at the centre of their ownership structures enjoy "strategic asymmetry" over their subsidiaries (Rugman and D'Cruz, 1997). Therefore, these firms hold an important role where they can exercise strategic behaviour 
control (Jarillo, 1988; Kano, 2018). We refer to these focal firms, holding a potentially important strategic position in the ownership network as lead firms (Strange and Humphrey, 2018). ${ }^{4}$ Table 4 presents a number of characteristics of the ownership network, including number of lead parent firms and subsidiaries; in this data there are 11 lead firms.

Kogut and Walker (2001) note that ownership networks are characterised by a low density and sparse populations, while Todeva (2006) emphasises hierarchical control. These characteristics can be clearly seen in the ownership network under examination in figure 4 and the information presented in table 4.

Figure 4 - Micro level ownership network

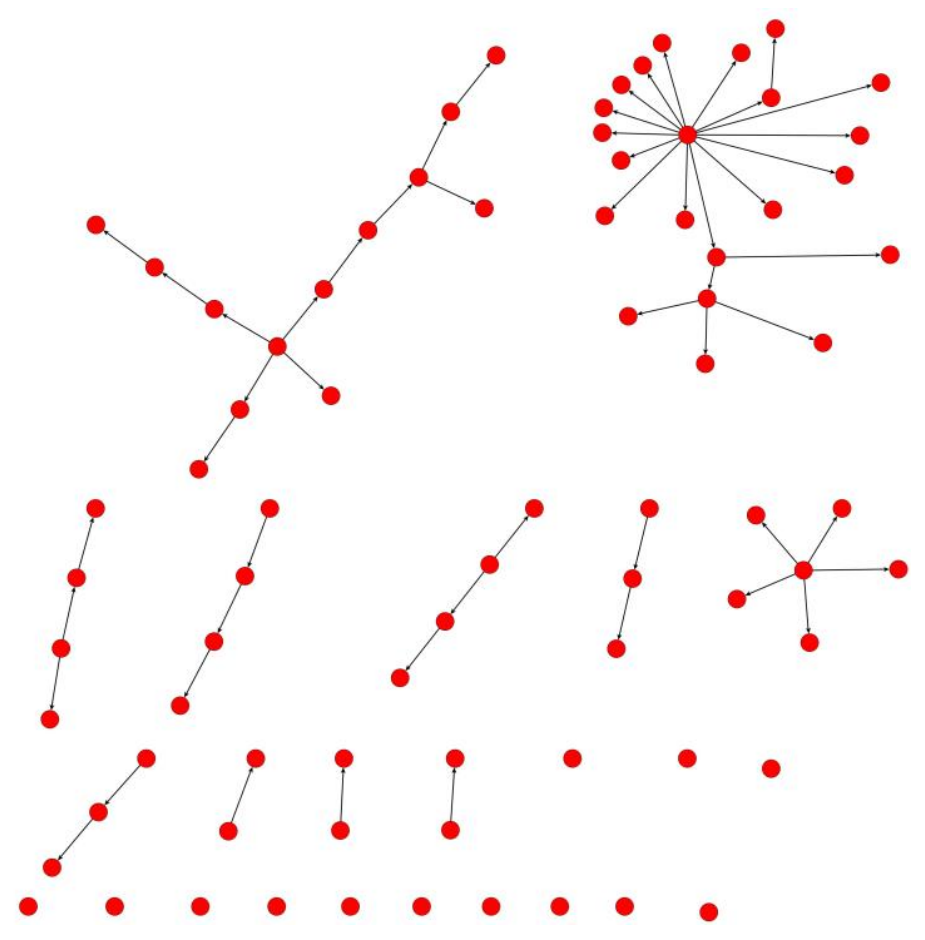

Table 4 - Ownership network summary statistics

\begin{tabular}{|l|l|}
\hline Number of firms & 68 \\
\hline Number of parent firms & 11 \\
\hline Number of subsidiaries & 57 \\
\hline Number of ownership ties & 54 \\
\hline
\end{tabular}

\footnotetext{
${ }^{4}$ Although, as noted by Strange and Humphrey (2018), these lead firms are often referred to by various other terms, such as flagship firms, network orchestrators and strategic centres.
} 


\section{The multilevel network model}

Models for multilevel network analysis have only become available recently, thanks to Wang et al. (2013) who introduced an extension of the Exponential Random Graph Model (ERGM) to the multilevel case. Since, there has been an influx of interest in multilevel network models, stimulated by the increased availability of rich datasets that can be analysed using these techniques (Lomi, Robins and Tranmer, 2016; Lazega and Snijders, 2015).

\subsection{Exponential Random Graph Model (ERGM)}

ERGMs are an established method for examining features of networks, with various empirical applications in political science (Ingold and Leifeld, 2014; Heaney, 2014), sociology (Lubbers and Snijders, 2007) and managerial studies (Arrieta-Paredes and Cronin, 2017). However, there are few applications of ERGMs to international trade and FDI, with the notable exception of Koskinen and Lomi (2013).

Local network configurations are an important part of ERGMs. These comprise a small subset of nodes and ties characterising a theoretical process; the model tests the propensity for this theoretical process to occur in the observed network (Robins et al., 2007). These local configurations represent the interdependencies between ties, and in the multilevel case, between levels. As noted by Zappa and Lomi (2015) in their detailed description of an empirical multilevel ERGM, typical statistical approaches often fail to capture these dependencies or treat them as part of the error term (Lusher et al., 2013).

The types of parameters that can be specified in the ERGM framework can be split into three groups: structural effects, node covariates and dyadic covariates. Structural effects are at the heart of the ERGM framework and allow us to directly model the interdependencies characterising the network. Second, the nodal covariates account for the formation of network ties as an outcome of the attribute of the actors themselves. Are nodes with a specific attribute more (or less) likely to send (or receive) ties? Node based effects can also be used to test for homophily in the network; are ties more likely to occur between actors with the same attribute in terms of international trade? We can test whether countries from the same region are more likely to trade. For continuous node-based covariates, there are also difference terms, which allow to test whether a tie between two actors is more likely when the value of the actors are similar, for example, this allows us to test whether countries of a similar size (in terms of GDP) are more likely to trade. Dyadic covariate effects model how another network 
(or relationship) influences the formation of ties, for example how the geographic distance matrix influence global trade.

Wang et al.'s (2013) extension of the ERGM to the multilevel case is a probability distribution where the structure of a typical graph is a cumulation of local processes both within and across levels. This extension takes into account the multiple networks involved, the macro network (denoted by A), the micro network (denoted by B) and the meso network (denoted by X).

This extension is expressed in the form:

$P(A=a, B=b, X=x)=$

$\frac{1}{k(\theta)} \exp \left(\sum \theta_{Q} z_{Q}(a)+\theta_{Q} z_{Q}(x)+\theta_{Q} z_{Q}(b)+\theta_{Q} z_{Q}(a, x)+\theta_{Q} z_{Q}(b, x)+\theta_{Q} z_{Q}(a, x, b)\right)$

Where:

$z_{Q}(a)$ and $z_{Q}(b)$ are the within level network statistics for the micro \& macro levels.

$z_{Q}(x)$ is the network statistic for the structural effects in the bipartite meso level.

$z_{Q}(a, x)$ and $z_{Q}(b, x)$ are the network statistics for the interactions between the macro and meso level networks and the micro and meso level networks respectively.

$z_{Q}(a, x, b)$ are the network statistics for the configurations that involve ties from all three networks.

The limitations of the multilevel ERGM are discussed by Zappa and Lomi (2015) and are mainly concerned with the models' inability to deal with weighted ties and longitudinal data. An important drawback of this model is that it requires the trade and ownership linkages to be dichotomized, as multilevel ERGMs can only deal with binary data. Nevertheless, this approach still provides a valuable tool for the analysis of the structure and patterns of international trade and investment.

\subsection{Multilevel network configurations}

The multilevel configurations span across the different levels, and involve the trade ties between nations, the firm-country affiliation ties and the ownership ties amongst firms. These configurations are outlined in table 5, along with their economic interpretation. These configurations allow to test for a wide range of informative structures in the data and have the 
potential to address a variety of research questions considering the international organisation of a high tech sector.

In the multilevel estimation, a level is usually fixed (although this is not a requirement). In this example, the structure of the ownership network was fixed, as this is the variable used to explain trade and investment patterns in the sector. Therefore, we do not present network configurations for the individual micro level. This practice is observed in the application of multilevel ERGMs, which often consider the micro (or macro) level and the meso level as exogenous (Zappa and Robins, 2016; Brennecke and Rank, 2016). This approach is often implemented due to data limitations, however, it also reduces the complexity of the model, and can aid in achieving a convergent and well-fitting model. In addition to fixing the micro level, we also fix the density at the macro and meso levels to promote model convergence.

The alternating affiliation based closure tests whether two countries are more likely to trade when they receive investments by the same firms. The affiliation based trading/ popularity/ activity effects allow to investigate how investment shapes international trade patterns, where we can test whether countries with a high level of investment have numerous import or export ties respectively in the ITN. There is also the possibility to test for whether there is a tendency for parents and subsidiaries to be located in the same nation through the domestic subsidiary effect.

The intra-firm trade parameter represents a form of cross-level exchange; here the assumption is made that the parent and subsidiary trade. The investigation of patterns of intra-firm trade is a unique aspect of the application of the multilevel ERGM to this dataset, given that data on intra-firm trade is widely unavailable.

Table 5 - Multilevel ERGM - multilevel configurations

\begin{tabular}{|l|l|}
\hline Configuration & Representation \\
\hline $\begin{array}{l}\text { Alternating affiliation } \\
\text { based closure } \\
\text { (ATXAXarc) }\end{array}$ & $\begin{array}{l}\text { Propensity for a set of firms based in two nations to } \\
\text { trigger a trade tie between them. }\end{array}$ \\
\hline $\begin{array}{l}\text { Affiliation based trading } \\
\text { (L3XAX) }\end{array}$ & $\begin{array}{l}\text { Propensity for nations with high levels of firm investment } \\
\text { to trade. }\end{array}$ \\
\hline
\end{tabular}




\begin{tabular}{|l|l|}
\hline $\begin{array}{l}\text { Affiliation } \\
\text { popularity } \\
\text { (AAinS1X) }\end{array}$ & $\begin{array}{l}\text { Propensity for countries with high levels of investment to } \\
\text { establish several import ties in the international trade } \\
\text { network. } \\
\text { This allows us to better understand the interplay between } \\
\text { investment and trade. Do firms invest for imports } \\
\text { (sourcing additional intermediate inputs) }\end{array}$ \\
\hline $\begin{array}{l}\text { Affiliation based activity } \\
\text { (AAoutS1X) }\end{array}$ & $\begin{array}{l}\text { Propensity for countries with high levels of investment to } \\
\text { establish several export ties in the international trade } \\
\text { network. } \\
\text { Again, this allows us to better understand the interplay } \\
\text { between investment and trade. Is a high level of firm } \\
\text { investment associated with a greater level of exports? }\end{array}$ \\
\hline $\begin{array}{l}\text { Domestic Subsidiary } \\
\text { (TriangleXBX) }\end{array}$ & $\begin{array}{l}\text { Propensity for two firms linked by ownership to be based } \\
\text { in the same nation i.e. the propensity for domestic } \\
\text { subsidiaries. }\end{array}$ \\
\hline $\begin{array}{l}\text { Intra-firm trade } \\
\text { (C4AXBexchange) }\end{array}$ & $\begin{array}{l}\text { Propensity for intra-firm trade } \\
\text { (AoutASXAoutBS) }\end{array}$ \\
\hline
\end{tabular}

Note: Red circles are firms and blue rectangles are nations. Configuration name used in MPNet given in parenthesis.

Our key interest here is in the interdependencies between levels, and what these can reveal about the structure of international trade and investment (and therefore production). When modelling these, however, we also specify effects at the macro (country to country trade network) and meso (firm-country affiliation network) levels as controls.

Table 6 provides an overview of the configurations included at these additional levels and their economic interpretation. In the covariate parameters, GDP (market size) is used as an example in the economic interpretation, other covariates included in the model are GDP per capita (market affluence), regional homophily (region match) and geographic distance. Regional homophily allows to capture whether trade is organised into regional blocks, and whether there is a tendency for regional production networks. Geographic distance, on the other hand, is included to test whether trade is dampened by distance (even within regional blocks), as predicted by the gravity model of international trade. 
There a number of structural parameters at the macro level which are used to control for the spread of trade ties or network centralisation (spread parameters), transitivity (closure and shared partner parameters) and reciprocity (for a full discussion of the additional types of parameters that can be specified in single level ERGMs see Snijders et al., 2006; Lusher et al., 2013; Wang et al., 2009).

Table 6 - Multilevel ERGM - Individual Level Configurations

\begin{tabular}{|c|c|c|}
\hline Configuration & Representation & Economic Interpretation \\
\hline $\begin{array}{l}\text { Reciprocity } \\
\text { (Macro Level) }\end{array}$ & & $\begin{array}{l}\text { Countries engaged in two-way, reciprocated } \\
\text { trade ties. They import and export to each other. }\end{array}$ \\
\hline $\begin{array}{l}\text { Sink } \\
\text { (Macro Level) }\end{array}$ & & $\begin{array}{l}\text { A country which imports but does not export } \\
\text { goods in the sector. (grey arrow represents a } \\
\text { missing tie) }\end{array}$ \\
\hline $\begin{array}{l}\text { Activity Spread } \\
\text { (Macro Level) }\end{array}$ & & $\begin{array}{l}\text { A few nations in the network have several export } \\
\text { ties to many other nations. }\end{array}$ \\
\hline $\begin{array}{l}\text { Popularity Spread } \\
\text { (Macro Level) }\end{array}$ & & $\begin{array}{l}\text { A few nations in the network have several import } \\
\text { ties from many other nations. }\end{array}$ \\
\hline $\begin{array}{l}\text { In degree }- \text { Out } \\
\text { degree } \\
\text { (Macro Level) }\end{array}$ & & $\begin{array}{l}\text { Captures the extent to which export and imports } \\
\text { are correlated. }\end{array}$ \\
\hline $\begin{array}{l}\text { Transitive Closure } \\
\text { (Macro Level) }\end{array}$ & & $\begin{array}{l}\text { Nations are more likely to trade with nations that } \\
\text { they share multiple trading partners. This } \\
\text { suggests hierarchical trading patterns with } \\
\text { country at the bottom benefiting from a stronger } \\
\text { exporting position. }\end{array}$ \\
\hline $\begin{array}{l}\text { Cyclic Closure } \\
\text { (Macro Level) }\end{array}$ & & $\begin{array}{l}\text { Propensity for (asymmetrical) trade occurring } \\
\text { within a subgroup of nations. }\end{array}$ \\
\hline $\begin{array}{l}\text { Shared in - partners } \\
\text { (Macro Level) }\end{array}$ & & $\begin{array}{l}\text { Propensity for importing nations to share } \\
\text { common import partners. (Importing from } \\
\text { common suppliers) }\end{array}$ \\
\hline $\begin{array}{l}\text { Shared out - partners } \\
\text { (Macro Level) }\end{array}$ & & $\begin{array}{l}\text { Propensity for active nations to share common } \\
\text { export partners (Exporting to common markets) }\end{array}$ \\
\hline
\end{tabular}




\begin{tabular}{|c|c|}
\hline $\begin{array}{l}\text { Shared out - partners } \\
\text { closure } \\
\text { (Macro Level) }\end{array}$ & $\begin{array}{l}\text { Propensity for active nations that export to } \\
\text { common partners also trade between themselves }\end{array}$ \\
\hline $\begin{array}{l}\text { Continuous Covariate } \\
\text { (Macro Level) }\end{array}$ & $\begin{array}{l}\text { GDP: } \\
\text { Sender/Receiver - Propensity for larger nations } \\
\text { to export/import respectively. } \\
\text { Sum/Difference/Product: } \\
\text { The likelihood of a tie is a function of the } \\
\text { attribute values of the countries involved in the } \\
\text { dyad. } \\
\text { Out2star: } \\
\text { Propensity for larger nations to have two export } \\
\text { ties. }\end{array}$ \\
\hline $\begin{array}{l}\text { Covariate } \\
\text { Match/Mismatch } \\
\text { (Macro Level) }\end{array}$ & $\begin{array}{l}\text { Regional Partition: } \\
\text { Match - Intra-Regional Trade } \\
\text { Mismatch - Inter-Regional trade }\end{array}$ \\
\hline $\begin{array}{l}\text { Three Path } \\
\text { (Meso Level) }\end{array}$ & $\begin{array}{l}\text { Propensity for firms to locate in nations with } \\
\text { many investors (and to link to other firms } \\
\text { indirectly) }\end{array}$ \\
\hline $\begin{array}{l}\text { Alternating Firm Star } \\
\text { (Meso Level) }\end{array}$ & $\begin{array}{l}\text { Propensity for a small number of firms in the } \\
\text { network to be linked to a large number of } \\
\text { nations. }\end{array}$ \\
\hline $\begin{array}{l}\text { Country Isolates } \\
\text { (Meso Level) }\end{array}$ & $\begin{array}{l}\text { Propensity for isolated nations in the meso level. } \\
\text { Nations that are present in the ITN, but do not } \\
\text { have an affiliation tie with a firm. }\end{array}$ \\
\hline
\end{tabular}

\section{Results}

\subsection{Model estimation}

Table 7 gives the results from the model estimation, where all estimation and goodness of fit procedures are conducted with the MPNet software (Wang et al., 2014). The parameter values provide an indication of the likelihood of the network configuration, given the other network configurations and effects specified in the model. A positive and significant configuration parameter would indicate that we are more likely to observe this configuration in the network under examination than by random chance.

Although the focus of this analysis is the multilevel parameters, and how these inform on the organisation of production in this sector, a brief discussion of the significant macro and meso level parameters will be provided. There is a strong and positive sink parameter, indicating the propensity for a number of nations to import goods in this sector, but not to export. This points towards the core-periphery structure of the trade network already identified in table 2. 
The popularity spread, activity spread, in-out degree and transitive closure parameters are all significant and point to a complex degree distribution of trade ties. The significant spread parameters, and their dampening partners ${ }^{5}$ indicate that trade ties are concentrated in a small handful of countries, which also lends support to the existence of a core-periphery structure (Chu-Shore, 2010). The triadic parameter results also support these findings; with the positive and significant transitive closure and negative (yet non-significant) cyclic closure. This suggests that there is a tendency for hierarchical transitive trading patterns, with a country holding a dominant exporting position (in these configurations). The remainder of the triadic configurations are non-significant, along with no significant tendency for nations to share export or import partners (or markets/suppliers). The covariate parameters at the macro level indicate that trade is a function of market size, as indicated by the significant GDP product and product reciprocity results. As predicted by the gravity model, distance is seen to have a dampening effect on bilateral trade ties.

The country isolates parameter is used to control for countries that are present in the international trade network, but where no firm from the micro level ownership network is affiliated with them. The other parameters are used to control for the spread of ties in the meso level. The meso level three path was included to control for the clustering in the firmcountry affiliation network.

The results from the multilevel analysis indicate a number of patterns that characterising international trade and investment (and therefore production) in the medical and precision instruments sector. These demonstrate a clear link between firm activity and trading patterns, allowing us to draw conclusions beyond simply noting associations between the two levels.

The multilevel configuration results presented in table 7 highlight the complex interplay between micro firm activity and macro trade patterns. In particular, this is demonstrated by the positive and significant alternating affiliation based closure parameter (0.1117), which indicates that a set of firms based in two countries triggers a trade tie between them. This result suggests that in this sector, trade and investment are highly interdependent, as observed in the literature, where multinational groups contribute the great majority of global trade (UNCTAD, 2013).

\footnotetext{
${ }^{5}$ In order to capture the skewed nature of the degree distribution, both spread parameters were included with different $\lambda$ values, where the $\lambda$ values were selected to promote model convergence.
} 
The multilevel intra-firm trade parameter presented in table 7 is non-significant. This is not surprising as the focus of this paper is on trade patterns within a segment of the value chain. Firms belonging to the product classification we analyse are likely to produce substitute goods, and therefore have no incentives in trading with each other.

The domestic subsidiary parameter is highly positive and significant (1.9529), as shown in table 7. This indicates that there is a tendency for domestic subsidiaries in the sector. The GDP per capita results at the macro level indicate that affluent nations are more likely to have multiple export ties (positive and significant GDP per capita out2star) yet are less likely to be importers in the sector (negative and significant GDP capita receiver). This reflects that larger affluent nations are able to source inputs domestically rather than importing.

Given the ownership network is characterised by a set of lead firms, we test how their investment patterns influence international trade at the macro level. The literature highlights the importance of lead firms as key players in the production process in high-tech sectors (Bamber and Gereffi, 2013). The positive and significant lead firm affiliation parameter in table 7 (0.2332) indicates that there is a tendency for lead or orchestrating firms (with a large number of subsidiaries) to be located in a country for multiple exports. This result confirms that lead firms play a significant role in the medical and precision instruments sector.

Two multilevel level parameters are included as control variables in the model, these are the subsidiary and parent-firm affiliation parameters. These parameters control for lack of connections in the ownership and firm-country affiliation network. These subsidiary and parent-firm affiliation parameters allows to control for this, where they are not the target of interpretation and discussion here, rather they ensure that the model converges with a good fit and does not suffer from degeneracy issues. 
Table 7 - Multilevel ERGM results

\begin{tabular}{|c|c|c|}
\hline Effects & $\begin{array}{l}\text { ERGM } \\
\text { Estimates (SE) } \\
\end{array}$ & \\
\hline Reciprocity & $0.7045(0.338)$ & * \\
\hline Sink & $3.5112(0.937)$ & $*$ \\
\hline $\begin{array}{l}\text { Popularity Spread } 1(\lambda=4) \\
\text { (AinSA) }\end{array}$ & $2.0298(0.259)$ & $*$ \\
\hline $\begin{array}{l}\text { Activity Spread 1( } \lambda=6) \\
\text { (AoutSA) }\end{array}$ & $0.9387(0.105)$ & $*$ \\
\hline $\begin{array}{l}\text { Popularity Spread } 2(\lambda=2) \\
\text { (AinSA2) }\end{array}$ & $-2.5631(0.758)$ & $*$ \\
\hline $\begin{array}{l}\text { Activity Spread } 2(\lambda=1.5) \\
\text { (AoutSA2) }\end{array}$ & $-3.0592(0.859)$ & * \\
\hline $\begin{array}{l}\text { In degree - Out degree } \\
\text { (AinAoutSA) }\end{array}$ & $1.2332(0.403)$ & $*$ \\
\hline $\begin{array}{l}\text { Transitive Closure } \\
\text { (ATA-T) }\end{array}$ & $1.5543(0.304)$ & * \\
\hline $\begin{array}{l}\text { Cyclic Closure } \\
\text { (ATA-C) }\end{array}$ & $-0.1183(0.087)$ & \\
\hline $\begin{array}{l}\text { Shared out - partners closure } \\
\text { (ATA-U) }\end{array}$ & $-0.0067(0.126)$ & \\
\hline $\begin{array}{l}\text { Shared in - partners } \\
\text { (A2PA-D) }\end{array}$ & $0.0087(0.017)$ & \\
\hline $\begin{array}{l}\text { Shared out - partners } \\
\text { (A2PA-U) }\end{array}$ & $0.06(0.041)$ & \\
\hline GDP Sum & $0.0513(0.065)$ & \\
\hline GDP Product & $1.6484(0.341)$ & * \\
\hline GDP Product Reciprocity & $-1.362(0.372)$ & $*$ \\
\hline GDP Per Capita Receiver & $-0.3358(0.073)$ & $*$ \\
\hline GDP Per Capita Difference & $-0.343(0.083)$ & $*$ \\
\hline GDP Per Capita Out2Star & $0.0182(0.003)$ & $*$ \\
\hline Region Match & $0.1844(0.138)$ & \\
\hline Distance & $-0.1486(0.062)$ & $*$ \\
\hline Three Path (X3Path) & $0.013(0.002)$ & $*$ \\
\hline Country Isolates & $1.8559(0.486)$ & $*$ \\
\hline $\begin{array}{l}\text { Alternating Firm Stars }(\lambda=4) \\
\text { (XASB) }\end{array}$ & $0.1416(0.143)$ & \\
\hline Affiliation based activity & $-0.2278(0.06)$ & * \\
\hline $\begin{array}{l}\text { Alternating - Affiliation based } \\
\text { closure }\end{array}$ & $0.1117(0.037)$ & $*$ \\
\hline Affiliation based trading & $0.0023(0.001)$ & $*$ \\
\hline Domestic Subsidiary & $1.9529(0.392)$ & $*$ \\
\hline Intra-firm trade & $-0.0041(0.005)$ & \\
\hline Lead Firm Affiliation & $0.2332(0.06)$ & $*$ \\
\hline $\begin{array}{l}\text { Subsidiary Affiliation } \\
\text { (In2StarBX) }\end{array}$ & $-0.2872(0.113)$ & $*$ \\
\hline $\begin{array}{l}\text { Parent Firm Affiliation } \\
\text { (Out2StarBX) }\end{array}$ & $-0.3161(0.095)$ & $*$ \\
\hline
\end{tabular}

We can also connect the results of this multilevel analysis to the literature on firm trade patterns and FDI, which allows us to draw further conclusions about the international 
organisation of production in this sector. More specifically, we draw on the work of Ivarsson and Johnsson (2000), who analyse the link between the presence of firm trading activity and the motives of firm FDI - more specifically what firms seek to acquire from their foreign investment - natural resources, new markets, efficiency benefits or strategic assets (technology organisational capabilities). The tendency against firms locating in a country to export (negative and significant affiliation based activity parameter, -0.2278) along with the non-significant intra-firm trade result indicates a motivation for FDI. The negative effect of investing to export (and non-significant intra firm trade) suggests that FDI in this sector is chiefly market seeking and strategic asset seeking (Ivarsson and Johnsson, 2000; Lanz and Miroudot, 2011).

A propensity for market seeking FDI suggests that subsidiaries serve end markets, reflecting the diversity of the medical and precision instruments sector, with countries with varying regulatory systems that require unique product customisation. Strategic asset seeking FDI allows multinational groups to complement their own firm specific capabilities (Ivarsson and Jonsson, 2003). In the case of the medical and precision instruments sector, this reflects the tendency for firms to invest in a country or participate in merger and acquisition activity in order to acquire regulatory approval certificates (an example of a strategic asset in this setting).

To conclude, while the substantial body of research on the FDI explains various features of location decisions of firms, such as how pure economic factors influence investment patterns (Nielsen et al., 2017), the impact of firm governance structure (including how multinational or business groups are linked by ownership ties) on the locational decisions of firms and internationalisation strategy is relatively understudied (Lien and Filatotchev, 2015; Jain et al., 2016). The multilevel approach presented here contributes to this stream of literature, by examining in unison the corporate structure of multinational groups and firm FDI location choices, alongside how these shape international trade patterns at the country-level. Additionally, this multilevel ERGM demonstrates how a multilevel network analysis can provide an insight into the international operations of firms in a sector, specifically providing an indication of the motives for FDI, the interplay between firm activity and global trade.

\subsection{Model goodness of fit}

After estimating the multilevel model, we carry out a goodness of fit exercise. The goodness of fit allows us to test how well the estimated model is able to reproduce the salient 
characteristics of the observed network. The goodness of fit procedure consists of simulating a large number of networks from the estimated ERGM and comparing characteristics of the simulated networks with the observed network. The multilevel model is able to reproduce all features of the network (not just those that were explicitly modelled), according to the criteria outlined by Robins et al. (2009). Table 8 presents the goodness of fit, where the t-ratios indicate how well the model explains the features of the observed network. As noted by Robins et al. (2007:177), the ERGM is not fitted to make "perfect deterministic predictions", that there will be some statistical noise that the model cannot successfully explain. Therefore, we do not expect a t-value of 0 (i.e. the fitted model replicates exactly all features of the observed network). Ideally, GOF t-ratio should be equal or lower than 0.1 , indicating that the observed network lies close to the average value of the fitted distribution at the 5\% level. However, following the established approach in the literature (Hunter et al., 2008), if the absolute value of the t-ratio is greater than 1.96, then the model is not able to explain or reproduce certain features of the observed network. Table 8 indicates that our model is able to reproduce the salient features of the observed network as all t-ratios are below 1.96, and in some cases close to 0.1 in absolute value.

Table 8 - Multilevel ERGM goodness of fit

\begin{tabular}{|l|c|cc|}
\hline Statistics & Observed & $\begin{array}{c}\text { Simulated Mean } \\
\text { (SE) }\end{array}$ & t-ratio \\
\hline Standard Deviation indegree distribution macro level & 5.1799 & $4.9093(0.394)$ & 0.686 \\
Skewness indegree distribution macro level & 0.8711 & $0.7212(0.205)$ & 0.73 \\
Standard Deviation outdegree distribution macro level & 14.4001 & $14.0067(0.581)$ & 0.677 \\
Skewness outdegree distribution macro level & 2.7472 & $2.6967(0.142)$ & 0.356 \\
Macro Level Clustering (tm) & 0.4911 & $0.4957(0.03)$ & -0.153 \\
Macro Level Clustering (cm) & 0.2454 & $0.2669(0.022)$ & -0.974 \\
Macro Level Clustering (ti) & 0.7111 & $0.7317(0.046)$ & -0.446 \\
Macro Level Clustering (to) & 0.1734 & $0.1791(0.017)$ & -0.33 \\
\hline Standard Deviation country degree distribution in the & & & \\
meso level & 4.9183 & $4.6862(0.429)$ & 0.541 \\
Skewness country Degree distribution in the meso level & 4.239 & $3.5208(0.673)$ & 1.067 \\
Standard Deviation firm degree distribution in the meso & & & \\
level & 5.1076 & $4.7614(0.367)$ & 0.942 \\
Skewness firm degree distribution in the meso level & 4.5724 & $4.4237(0.542)$ & 0.274 \\
Meso Level Clustering & 0.2232 & $0.2270(0.029)$ & -0.128 \\
\hline
\end{tabular}

\section{Concluding Comments}

The problem of creating and analysing datasets that combine firm-level and country-level network data in order to better explain the international organisation of production is something that many scholars and international organisations are attempting to address. This 
paper has discussed how the application of a multilevel network model to data from a hightech sector enables to better explain the international organisation of that sector, providing insights on patterns of trade, investment patterns and motives. More specifically the analysis indicates how the corporate structure of firms in business groups and their investment decisions at the micro level shape international trade patterns at the macro level.

Although there are limitations to the multilevel ERGM approach presented here, namely the models' inability to deal with weighted ties and longitudinal data, the paper demonstrates the value of this type of approach.

There are a number of avenues for future research, in particular the extension of the multilevel model and dataset to other sectors or segments within a sector. There is scope to extend this approach to allow for comparison across industries with different technological content and to better understand patterns of trade and investments in the global economy. There is also scope to expand this analysis to different segments of the medical and precision industry value chain. Here we have focused on the production of goods, but this could be expanded to include for example activities ranging from research and design to end use. The extension of the multilevel dataset to encompass the full range of segments of the medical and precision instruments GVC would allow a more detailed investigation of patterns of intra-firm trade. 


\section{References}

Altomonte, C. and Rungi, A. (2013) Business Groups as Hierarchies of Firms: Determinants of Vertical Integration and Performance, Fondazione Eni Enrico Mattei, Available at: http://econpapers.repec.org/RePEc:fem:femwpa:2013.33.

Amighini, A. and Gorgoni, S. (2014) The international reorganisation of auto production, The World Economy, 37(7), pp. 923-952.

Antràs, P. (2003) Firms, contracts, and trade structure, The Quarterly Journal of Economics, 118(4), pp. 1375-1418.

Antràs, P. (2005) Property rights and the international organization of production, American economic review, 95(2), pp. 25-32.

Antràs, P. and Chor, D. (2013) Organizing the global value chain, Econometrica, 81(6), pp. 2127-2204.

Antràs, P. and Rossi-Hansberg, E. (2009) Organizations and Trade, Annual Review of Economics, 1(1), pp. 43-64.

Antràs, P. and Yeaple, S. R. (2014) Multinational firms and the structure of international trade, In Handbook of international economics, Elsevier, pp. 55-130.

Arrieta-Paredes, M.-P. and Cronin, B. (2017) Exponential random graph models for management research: A case study of executive recruitment, European Management Journal, 35(3), pp. 373-382.

Baldwin, R. and Robert-Nicoud, F. (2014) Trade-in-goods and trade-in-tasks: An integrating framework, Journal of International Economics, 92(1), pp. 51-62.

Baldwin, R. and Venables, A. J. (2013) Spiders and snakes: Offshoring and agglomeration in the global economy, Journal of International Economics, 90(2), pp. 245-254.

Bamber, P. and Gereffi, G. (2013) Costa Rica in the Medical Devices Global Value Chain, Durham: Duke University, Center on Globalization, Governance and Competitiveness.

Baur, M., Benkert, M., Brandes, U., Cornelsen, S., Gaertler, M., Köpf, B., Lerner, J. and Wagner, D. (2001) Visone Software for visual social network analysis, In International Symposium on Graph Drawing, Springer, pp. 463-464. 
Bernard, A. B. and Moxnes, A. (2018) Networks and Trade, Annual Review of Economics, 10(1), pp. 65-85.

Bernard, A. B., Redding, S. J. and Schott, P. K. (2007) Comparative advantage and heterogeneous firms, The Review of Economic Studies, 74(1), pp. 31-66.

Blázquez, L. and González-Díaz, B. (2016) International automotive production networks: How the web comes together, Journal of Economic Interaction and Coordination, 11(1), pp. 119-150.

Borgatti, S. P., Everett, M. G. and Freeman, L. C. (2002) Ucinet for Windows: Software for Social Network Analysis, Harvard, MA, Analytic Technologies.

Brennecke, J. and Rank, O. N. (2016) The interplay between formal project memberships and informal advice seeking in knowledge-intensive firms: A multilevel network approach, Social Networks, 44, pp. 307-318.

Cadestin, C., Backer, K. D., Desnoyers-James, I., Miroudot, S., Ye, M. and Rigo, D. (2018) Multinational enterprises and global value chains, Available at: https://www.oecdilibrary.org/content/paper/194ddb63-en.

Chaney, T. (2008) Distorted gravity: the intensive and extensive margins of international trade, American Economic Review, 98(4), pp. 1707-21.

Charbonneau, K. B. (2017) Multiple fixed effects in binary response panel data models, The Econometrics Journal, 20(3), pp. S1-S13.

Chu-Shore, J. (2010) Homogenization and Specialization Effects of International Trade: Are Cultural Goods Exceptional?, World Development, 38(1), pp. 37-47.

De Backer, K., De Lombaerde, P. and Iapadre, L. (2018) Analyzing Global and Regional Value Chains, International Economics, SI: Global Value Chains, 153, pp. 3-10.

De Benedictis, L., Nenci, S., Santoni, G., Tajoli, L. and Vicarelli, C. (2014) Network Analysis of World Trade using the BACI-CEPII dataset, Global Economy Journal, 14(3-4), pp. 287-343.

De Benedictis, L. and Tajoli, L. (2011) The World Trade Network, The World Economy, 34(8), pp. 1417-1454. 
Del Prete, D. and Rungi, A. (2017) Organizing the Global Value Chain: a firm-level test, Journal of International Economics, 109, pp. 16-30.

Eurostat (2017) RAMON - Reference and management of nomenclatures, European Commission, Available at: http://ec.europa.eu/eurostat/ramon.

Fagiolo, G., Reyes, J. and Schiavo, S. (2009) World-trade web: Topological properties, dynamics, and evolution, Physical Review E, 79(3), p. 036115.

Feenstra, R. C., Lipsey, R. E., Branstetter, L. G., Foley, C. F., Harrigan, J., Jensen, J. B., Kletzer, L., Mann, C., Schott, P. K. and Wright, G. C. (2010) Report on the State of Available Data for the Study of International Trade and Foreign Direct Investment, Working Paper, National Bureau of Economic Research, Available at: http://www.nber.org/papers/w16254. Gammeltoft, P., Barnard, H. and Madhok, A. (2010) Emerging multinationals, emerging theory: Macro-and micro-level perspectives, Journal of International Management, 16(2), pp. 95-101.

Garlaschelli, D. and Loffredo, M. I. (2005) Structure and evolution of the world trade network, Physica A: Statistical Mechanics and its Applications, 355(1), pp. 138-144.

Gereffi, G., Humphrey, J. and Sturgeon, T. (2005) The governance of global value chains, Review of International Political Economy, 12(1), pp. 78-104.

Glattfelder, J. B. and Battiston, S. (2009) Backbone of complex networks of corporations: The flow of control, Physical Review E, 80(3), p. 036104.

Gorgoni, S., Amighini, A. and Smith, M. (2018) Automotive international trade networks: A comparative analysis over the last two decades, Network Science, 6(4), pp. 571-606.

Graham, B. S. (2015) Methods of identification in social networks, Annu. Rev. Econ., 7(1), pp. $465-485$.

Gray, H. P. (1996) The eclectic paradigm: The next generation, Transnational Corporations, 5(2), pp. 51-65.

Grossman, S. J. and Hart, O. D. (1986) The costs and benefits of ownership: A theory of vertical and lateral integration, Journal of political economy, 94(4), pp. 691-719.

Grossman, G. M. and Rossi-Hansberg, E. (2008) Trading Tasks: A Simple Theory of Offshoring, American Economic Review, 98(5), pp. 1978-1997. 
Haller, S. A. (2012) Intra-firm trade, exporting, importing, and firm performance, Canadian Journal of Economics/Revue canadienne d'économique, 45(4), pp. 1397-1430.

Handcock, M. S., Hunter, D. R., Butts, C. T., Goodreau, S. M., Krivitsky, P. N. and Morris, M. (2016) statnet: Software Tools for the Statistical Modeling of Network Data, Seattle, WA, Available at: http://CRAN.R-project.org/package=statnet.

Hanson, G. H., Mataloni, R. J. and Slaughter, M. J. (2005) Vertical Production Networks in Multinational Firms, Review of Economics and Statistics, 87(4), pp. 664-678.

Heaney, M. T. (2014) Multiplex networks and interest group influence reputation: An exponential random graph model, Social Networks, Special Issue on Political Networks, 36, pp. 66-81.

Helg, R. and Tajoli, L. (2005) Patterns of international fragmentation of production and the relative demand for labor, North American Journal of Economics and Finance, 16(2), pp. 233-254.

Helpman, E. (2014) Foreign trade and investment: Firm-level perspectives, Economica, 81(321), pp. 1-14.

Helpman, E., Melitz, M. J. and Yeaple, S. R. (2004) Export versus FDI with heterogeneous firms, American economic review, 94(1), pp. 300-316.

Hunter, D. R., Goodreau, S. M. and Handcock, M. S. (2008) Goodness of fit of social network models, Journal of the American Statistical Association, 103(481), pp. 248-258.

Iapadre, P. L. and Tajoli, L. (2014) Emerging countries and trade regionalization. A network analysis, Journal of Policy Modeling, Measuring and Modeling Regional Power and Leadership, 36, pp. S89-S110.

Ingold, K. and Leifeld, P. (2014) Structural and institutional determinants of influence reputation: A comparison of collaborative and adversarial policy networks in decision making and implementation, Journal of public administration research and theory, 26(1), pp. $1-18$.

Irarrazabal, A., Moxnes, A. and Opromolla, L. D. (2013) The margins of multinational production and the role of intrafirm trade, Journal of Political Economy, 121(1), pp. 74-126. ISDATA (2017) The industrial symbiosis data repository, Available at: http://isdata.org. 
Ivarsson, I. and Johnsson, T. (2000) Tnc strategies and variations in intra-firm trade: the case of foreign manufacturing affiliates in sweden, Geografiska Annaler: Series B, Human Geography, 82(1), pp. 17-34.

Ivarsson, I. and Jonsson, T. (2003) Local technological competence and asset-seeking FDI: an empirical study of manufacturing and wholesale affiliates in Sweden, International Business Review, 12(3), pp. 369-386.

Jain, N. K., Kothari, T. and Kumar, V. (2016) Location Choice Research: Proposing New Agenda, Management International Review, 56(3), pp. 303-324.

Jarillo, J. C. (1988) On strategic networks, Strategic Management Journal, 9(1), pp. 31-41.

Johnson, R. C. (2014) Five Facts about Value-Added Exports and Implications for Macroeconomics and Trade Research, Journal of Economic Perspectives, 28(2), pp. 119142.

Johnson, R. C. and Noguera, G. (2017) A Portrait of Trade in Value-Added over Four Decades, The Review of Economics and Statistics, 99(5), pp. 896-911.

Jones, R. W. and Kierzkowski, H. (2005) International fragmentation and the new economic geography, The North American Journal of Economics and Finance, 16(1), pp. 1-10.

Kali, R. and Reyes, J. (2007) The architecture of globalization: a network approach to international economic integration, Journal of International Business Studies, 38(4), pp. 595620.

Kano, L. (2018) Global value chain governance: A relational perspective, Journal of International Business Studies, 49(6), pp. 684-705.

Keller, W. and Yeaple, S. R. (2013) The gravity of knowledge, American Economic Review, 103(4), pp. 1414-44.

Knoke, D. and Yang, S. (2008) Social network analysis, Sage.

Kogut, B. and Walker, G. (2001) The small world of Germany and the durability of national networks, American Sociological Review, 66(3), pp. 317-335.

Koskinen, J. and Lomi, A. (2013) The local structure of globalization, Journal of statistical physics, 151(3-4), pp. 523-548. 
Lall, S., Weiss, J. and Zhang, J. (2006) The ‘sophistication' of exports: A new trade measure, World Development, 34(2), pp. 222-237.

Lanz, R. and Miroudot, S. (2011) Intra-Firm Trade, OECD Trade Policy Papers, Paris, Organisation for Economic Co-operation and Development, Available at: http://www.oecdilibrary.org/content/workingpaper/5kg9p391rwnn-en.

Lazega, E. and Snijders, T. A. (2015) Multilevel network analysis for the social sciences: theory, methods and applications, Springer.

Lien, Y.-C. and Filatotchev, I. (2015) Ownership characteristics as determinants of FDI location decisions in emerging economies, Journal of World Business, 50(4), pp. 637-650.

Lomi, A., Robins, G. and Tranmer, M. (2016) Introduction to multilevel social networks, Social Networks, 44, pp. 266-268.

Lubbers, M. J. and Snijders, T. A. B. (2007) A comparison of various approaches to the exponential random graph model: A reanalysis of 102 student networks in school classes, Social Networks, 29(4), pp. 489-507.

Lusher, D., Koskinen, J. and Robins, G. (2013) Exponential random graph models for social networks: Theory, methods, and applications, Cambridge University Press.

Melitz, M. J. (2003) The impact of trade on intra-industry reallocations and aggregate industry productivity, Econometrica, 71(6), pp. 1695-1725.

Metulini, R., Riccaboni, M., Sgrignoli, P. and Zhu, Z. (2017) The indirect effects of foreign direct investment on trade: A network perspective, The World Economy, 40(10), pp. 21932225 .

Miroudot, S., Lanz, R. and Ragoussis, A. (2009) Trade in intermediate goods and services, OECD Publishing, Available at:

http://www.abhatoo.net.ma/index.php/fre/content/download/15082/262506/file/Trade_in_Inte rmediate_Goods_and_Services.pdf.

Nielsen, B. B., Asmussen, C. G. and Weatherall, C. D. (2017) The location choice of foreign direct investments: Empirical evidence and methodological challenges, Journal of World Business, 52(1), pp. 62-82. 
Nielsen, P. B. (2018) The puzzle of measuring global value chains - The business statistics perspective, International Economics, SI: Global Value Chains, 153, pp. 69-79.

OECD (2013) Interconnected Economies: Benefiting from Global Value Chains (Preliminary Version), OECD Publishing.

Pan, Z. (2018) Varieties of intergovernmental organization memberships and structural effects in the world trade network, Advances in Complex Systems, 21(02), p. 1850001.

Park, I. and Park, S. (2015) Modes of Foreign Direct Investment and Patterns of Trade: An Alternative Empirical Approach, The World Economy, 38(8), pp. 1225-1245.

Porter, M. E., Ramirez-Vallejo, J., Puri, A., Demirsoy, I., Woods, L., Zhou, M. and Rattanaruengyot, T. (2011) The Minnesota medical devices cluster, Microeconomics of Competitiveness, pp. 1-36.

Ramondo, N. (2014) A quantitative approach to multinational production, Journal of International Economics, 93(1), pp. 108-122.

Ramondo, N., Rappoport, V. and Ruhl, K. J. (2016) Intrafirm trade and vertical fragmentation in U.S. multinational corporations, Journal of International Economics, 98, pp. $51-59$.

Robins, G., Pattison, P., Kalish, Y. and Lusher, D. (2007) An introduction to exponential random graph (p*) models for social networks, Social Networks, 29(2), pp. 173-191.

Robins, G., Pattison, P. and Wang, P. (2009) Closure, connectivity and degree distributions: Exponential random graph ( $\left.\mathrm{p}^{*}\right)$ models for directed social networks, Social Networks, 31(2), pp. $105-117$.

Rungi, A., Morrison, G. and Pammolli, F. (2017) Global ownership and corporate control networks, EIC Working Paper Series, IMT Institute for Advanced Studies Lucca.

Rugman, A. and D'Cruz, J. (1997) The theory of the flagship firm, European Management Journal, 15(4), pp. 403-412.

Shore, J. C. (2016) Market formation as transitive closure: The evolving pattern of trade in music, Network Science, 4(2), pp. 164-187.

Smith, D. A. and White, D. R. (1992) Structure and Dynamics of the Global Economy: Network Analysis of International Trade 1965-1980, Social Forces, 70(4), pp. 857-893. 
Snijders, T. A., Pattison, P. E., Robins, G. L. and Handcock, M. S. (2006) New specifications for exponential random graph models, Sociological methodology, 36(1), pp. 99-153.

Srholec, M. (2006) Fragmentation and trade: A network perspective, In 8th ETSG Annual Conference, Vienna, pp. 7-9, Available at: http://etsg.org/ETSG2006/papers/Srholec.pdf.

Strange, R. and Humphrey, J. (2018) What lies between market and hierarchy? Insights from internalization theory and global value chain theory, Journal of International Business Studies, 1-13, Available at: https://doi.org/10.1057/s41267-018-0186-0.

Sturgeon, T., Gereffi, G., Guinn, A. and Zylberberg, E. (2016) Brazil in Global Value Chains, MIT-IPC Working Paper.

Timmer, M. P., Los, B., Stehrer, R. and De Vries, G. J. (2013) Fragmentation, incomes and jobs: an analysis of European competitiveness, Economic policy, 28(76), pp. 613-661.

Todeva, E. (2006) Business networks, London, Routledge.

UNCTAD (2013) Global Value Chains and Development: Investment and Value Added Trade in the Global Economy: A Preliminary Analysis, United Nations: New York and Geneva, Available at: http://unctad.org/en/PublicationsLibrary/diae2013d1_en.pdf.

Vitali, S. and Battiston, S. (2014) The Community Structure of the Global Corporate Network, PLOS ONE, 9(8), p. e104655.

Vitali, S., Glattfelder, J. B. and Battiston, S. (2011) The Network of Global Corporate Control, PLoS ONE, 6(10), p. e25995.

Wacker, K. M. (2016) (When) Should We Use Foreign Direct Investment Data to Measure the Activities of Multinational Corporations? Theory and Evidence, Review of International Economics, 24(5), pp. 980-999.

Wang, P., Robins, G., Pattison, P. E. and Koskinen, J. H. (2014) MPNet: program for the simulation and estimation of $\left(\mathrm{p}^{*}\right)$ exponential random graph models for multilevel networks, Melbourne School of Psychological Sciences, The University of Melbourne, Melbourne, Australia.

Wang, P., Robins, G., Pattison, P. and Lazega, E. (2013) Exponential random graph models for multilevel networks, Social Networks, 35(1), pp. 96-115. 
Wang, P., Sharpe, K., Robins, G. L. and Pattison, P. E. (2009) Exponential random graph (p*) models for affiliation networks, Social Networks, 31(1), pp. 12-25.

Ward, M. D., Ahlquist, J. S. and Rozenas, A. (2013) Gravity's rainbow: A dynamic latent space model for the world trade network, Network Science, 1(1), pp. 95-118.

Yeaple, S. R. (2009) Firm heterogeneity and the structure of US multinational activity, Journal of International Economics, 78(2), pp. 206-215.

Yi, K.-M. (2003) Can vertical specialization explain the growth of world trade?, Journal of Political Economy, 111(1), pp. 52-102.

Zappa, P. and Lomi, A. (2015) The analysis of multilevel networks in organizations: Models and empirical tests, Organizational Research Methods, 18(3), pp. 542-569.

Zappa, P. and Robins, G. (2016) Organizational learning across multi-level networks, Social Networks, 44, pp. 295-306.

Zhou, M., Wu, G. and Xu, H. (2016) Structure and formation of top networks in international trade, 2001-2010, Social Networks, 44, pp. 9-21.

Zhu, Z., Cerina, F., Chessa, A., Caldarelli, G. and Riccaboni, M. (2014) The rise of China in the international trade network: a community core detection approach, PloS one, 9(8), p. e105496. 